\title{
Factors Affecting Learner Autonomy in Learning English at Tertiary Level: A Study at Ho Chi Minh City University of Technology
}

\author{
Tran Thi Bich Tram, M.A*, Vuong Tuyet Kha, M.A. \\ Van Lang University, Vietnam
}

*Corresponding Authors: Tran Thi Bich Tram, M.A, Van Lang University, Vietnam

\begin{abstract}
At the age of Industrial Revolution 4.0, learning is acknowledged as a livelong process of which learner autonomy is one of the most crucial components. A great number of studies have shown that autonomous language learners gain more benefits than those with passive approaches. Researchers also anticipated that enhancing their autonomy would greatly contribute to the increase in quality of English teaching and learning process. As a result, mastering the factors that influence learner autonomy is critical. This study aimed to find out the factors that both facilitate and hinder the development of learner autonomy. Both qualitative and quantitative approaches were employed to collect data from 233 English-majored students at Ho Chi Minh University of Technology (HUETCH). The findings revealed that there are some factors that not only assist but also obstruct English learners' ability to work autonomously. The study also found that factors in terms of intrinsic drive, learning preferences, technological advancements, and the people around them all promote their autonomous learning. It is suggested that teachers' perspectives on factors influencing learner autonomy should be taken into consideration.
\end{abstract}

Keywords: English-majored students, learner autonomy, hindering factors, facilitating factors

List of abbreviations: EFL: English as 0061 Foreign Language, HUTECH: Hochiminh City University of Technology, LA: Learner Autonomy, S: Student

\section{INTRODUCTION}

It is well acknowledged among educators that the number of English as foreign language students is increasing (EFL). Nevertheless, due to the consequences of long-standing conventional teaching and learning practices, the act of teaching and learning English in Vietnam has encountered a range of problems. During the learning process, Vietnamese students often learn by rote and try to memorize information provided instead of discovering things by themselves (Nguyen, 2010). Recently, it has recently been observed that traditional teacher-centered classrooms are giving ways to learnercentered classrooms. However, students are still likely to rely a lot on instructions and assignments given by their teacher. They show a tendency to follow existing or given pattern or framework rather than implementing what they have learned or even generating new knowledge in real life (Pham, 2010). Furthermore, teachers and learners of English in Vietnam have been facing difficulties regarding learning materials. Although teachers at tertiary level are allowed to create their own course materials, they must comply with specific guidelines and students have no say in the design and selection of course materials.

Such above-mentioned issues are linked to learner autonomy (LA) which was initiated by Holec (1981, p. 3) as "the capacity of taking charge of ones' own learning" and "the responsibility for all the decisions concerning all aspects of this learning". Moreover, according to Scharle \& Szabó (2000), LA was confirmed as a person's ability to handle his own affairs and self-determination. In other words, it refers to the fact that students are capable of acting freely without the need for a teacher's permission, and that they may interrupt a teacher's explanation to ask questions, etc. On the way to figure out beliefs in LA in Vietnam, Nguyen (2011) and Nguyen, Chung, Truong, and Pham (2014) indicated that both learners and teachers have recognized significant roles of learner autonomy.

According to Dinh (2017), since 2007 there are at least 25 studies have been conducted to study the role of LA in learning a foreign language in Vietnam. Almost none of them, however, indicated what facilitate and hinder the development of LA among Vietnamese learners of English. This research was 
carried out to determine what factors influence the development of learner autonomy in Englishmajored students in Vietnam.

\section{Aims And ObJectives Of The STUdy}

This study is carried out in high hopes that it may contribute to enhancement of LA among students of English in Vietnam in general and HUTECH English-majored students, in particular. Therefore, it aims to investigate both the factors that encourage and those that limit autonomous learning among English-majoring students at HUTECH during their EFL studies.

\section{LITERATURE REVIEW}

\subsection{Learner Autonomy}

Holec (1981, p. 3) clarified LA as "the capacity of taking charge of ones' own learning". The researcher believes that learners will take "the responsibility for all the decisions concerning all aspects of this learning" including establishing their own learning objective, selecting materials, choosing methods and techniques for learning, self-monitoring and giving assessment to their learning procedures (Holec, 1981). In addition, based on Holec's perspectives, Benson (2001) confirmed that autonomy in language learning hints the control over the learning cognitive process, management and contents. It is clear to emphasize that students are responsible for their own learning and play more active roles throughout such process, regardless of how LA has been understood and defined. Students are encouraged to decide their own learning materials, methods, assessment, as well as to develop their own learning techniques (Richards \& Rodgers, 2015).

\subsection{Autonomous Language Learners}

Many characteristics of autonomous learners are thought to present in educational settings. According to Littlewood (1996), they are people who are capable to and willing to make every learning decision on their own including setting learning targets, selecting learning resources and establishing criteria for learning strategies. Breen and Mann (1997) agree with Littlewood (1996) and add that autonomous learners possess an intrinsic motivation to learn the language. Similarly, Wenden (1998) has the same views with these researchers when indicating that autonomous learners often apply active approaches and are inclined to take risks as well as make good projections in their learning. They value both accuracy and appropriateness in the learning. They have abilities to establish a system of reference on their own to improve the target language and are prepared to reject any hypothesized concepts or regulations that cannot be used in learning process. They have the ability to create their own system of reference in order to improve the target language, and they are willing to dismiss any postulate or rules that cannot be applied to the learning process. According to Little (2000), autonomous learners are able to recognize the purposes of choosing learning topics, take ownership of the learning process, plan and carry out learning activities in a proactive and constructive manner. Learning a new language necessitates these skills. Wenden (1998) and Crabbe (1999) also reveals that such learners are not only capable of working independently but also of negotiating well with others in a socially acceptable manner. Besides, they own the ability to evaluate their learning outcomes, are prepared to learn from both their success as well as failures (Crabbe, 1999). This perspective on autonomous learner is also emphasized by Hasim and Zakaria (2015). On one hand, they are self-sufficient and do not wait for teachers to show them what to do. To put in another way, autonomous learners prefer to take an active role in obtaining information rather than passively receiving it. They are, on the other hand, willing to work with classmates or teachers both inside and outside the classroom (Hasim \& Zakaria, 2015). Besides, Morbedadze (2015) defines autonomous learner, in his own learning process, as a self-activated or active individual who makes things happen rather than waiting for them to happen.

\subsection{Factors Influencing EFL Learner Autonomy}

There have been various attributes to the factors influencing the development of LA in both positive and negative ways. In this study, such factors are classified into two groups known as internal and external factors. 


\subsubsection{Internal Factors}

\subsubsection{Psychological Aspects}

Researchers, for recent years, have pointed out that individual psychological aspects such as attitudes, motivation and preferences, as well as anxiety have been shown to influence how autonomous a learner is.

Wenden (1998) reveals that learners' attitude and self-beliefs affect their learning performance. If a learner thinks that he lacks the ability to learn, he may not put in sufficient effort. In other words, it fails to contribute positively to the development of LA. Besides, Yuen Pan (1997) believes that individual desire, ability and needs have a great impact on making learners to be more autonomous. In support of this, Qin (2016) points out that if learners are eager to learn, they will probably have positive attitudes. As a result, they will pay greater attention to studying and will almost certainly set learning goals. This develops autonomy. With the similar points of view, Coppersmith (1967) states that the learners with high self-esteem will be likely to achieve success. Leaver, Ehrman and Shekhtman (2005) also support this. It is believed by such authors that trust in oneself and in others was critical in paving the way for self-regulation and, therefore, enhanced autonomy. Simultaneously, they highlighted the balance between self-belief and faith in others. It means that learners take initiatives to seek out helps from others while they are learning. Furthermore, Chen (2015) also acknowledged the importance of self-efficacy in improving a variety of aspects of LA, including setting learning targets and objectives, selecting learning strategies, and monitoring learning. It is widely accepted that students with strong self-efficacy are more likely to be autonomous.

Moreover, many researchers have agreed that motivation plays an important role in fostering LA. For example, Dickinson (1992) reckons that motivation may be a precondition for LA. Besides, according to Spratt, Humphreys, and Chan (2002), the higher the level of motivation among Hong Kong students, the more engagement they exhibit in learning activities, and vice versa. Also, it is indicated by Chen (2015) that learners having high level of motivation are probably to do better in choosing and applying learning strategies, which is one of the dimensions of LA.

Another element that has a detrimental impact on LA is the fear of learning a new language. The more worried learners are, the less autonomous they become, according to Zaqiri (2015) and Chen (2015). This could be explained by the fact that such pupils are typically introverted, reliant on teachers, and mostly are not risk-takers (Zaqiri, 2015).

\subsubsection{Learning Styles and Learning Strategies}

Begum \& Chowdhury (2015) believe that different learners have distinct learning styles and tend to apply various learning strategies. Therefore, they assume that such learning styles and strategies are likely to either enhance or restrict learners' autonomy

\section{Positivism}

This learning approach emphasizes the importance of teachers in the classroom as knowledge transmitters. As a result, learners will be passive receivers, with little motivation to set learning goals or make decisions. This is in direct opposition to LA, obstructing its development.

\section{Constructivism}

This method helps students to derive new information from the knowledge foundation they already have. Students are also encouraged to discover things on their own. It is against positivism style; hence, support the development of LA.

\section{Critical theory}

Leaver, et al (2005) realizes that abstract thinking is beneficial to LA. Rather than attempting to understand and explain things, the theory promotes critique and change. Therefore, it allows students to learn autonomously and develop their own concepts. This enables learners to examine the subject in a variety of ways, which can help them decide whether to pursue or abandon the problem.

\section{Cognitive strategies}

These strategies allow learners to apply mental processes in language learning and involve different techniques such as repetition, resourcing, translating, note-taking, deduction, contextualization, 
transferring, inference and clarifying questions. When learners master the use of these tools, they become autonomous.

\section{Metacognitive strategies}

Planning, thinking, monitoring, and analyzing a person's learning are some of these strategies. Learners who own them are engaged and self-directed in their learning, and they have good selfregulation, which LA heavily relies on (Leaver et al, 2005). Çakici $(2015$, p. 36) agrees with the idea that by using these tactics, students will become more cooperative and confident in their learning.

\subsubsection{Developed Skills and Awareness}

Balçikanli (2010) indicates that the shortage of learning skills and knowledge brings substandard performance of self-study. Similarly, Tran and Duong (2018) support that students will be more optimistic and independent if they have some knowledge, awareness and/or skills in specific areas related to their learning task

\subsubsection{External Factors}

\subsubsection{The Teachers}

In order to help improve LA, teachers are said by many researchers to take a variety of roles rather than just the transmitter of knowledge in traditional classrooms. Little (1996) stated that though autonomous learners' ability to be responsible for their learning, it did not necessarily mean that they would automatically do so without the help of the instructors. Teachers were believed to play multiple roles rather than just the source of information in conventional classrooms. Leaver et al (2005) and Kemala (2016) points out the decisive connection between teachers and students. They assume that teachers not only help raise students' awareness of establishing learning objectives, choosing learning materials, etc. but also offer them opportunities to make their own choices. Alonazi (2017) in a research finds that teachers should play multi roles such as facilitator, counselor, resource and manager in order to encourage students to be more autonomous. In addition, Tran and Duong (2018) report that English language teachers also can act as a facilitators, mentors (or counsellors) and resources.

\subsubsection{The Tasks}

Kemala (2016) proves that tasks that must be done have a significant impact on LA, either positively or negatively. When students are working on projects that are both interesting and hard, they will be more motivated. On the contrary, students may lack drive for uninteresting projects. This viewpoint is, somehow, similar to that of Tran and Duong (2018). According to their findings, students who realize the meaningfulness of a particular given task (i.e. portfolio), find that it brings a variety of benefits including self-awareness of learning, improved self-management, self-assessment, decisionmaking abilities, and so on.

\subsubsection{The Environment}

Benson (2001, p. 49) says that both social and situational aspects of environmental factors have a significant impact on LA. The social aspect refers to the learners' environment, such as parents, siblings, relatives, friends and teachers. What impact may they have on students? Autonomous learners, on the other hand, require interactions, and this social context may make it easier for learners to collaborate and communicate with others in the classroom. Similarly, Dang's (2010) study revealed that students in Vietnam nowadays students find it simpler to exchange information, share resources and discuss how to complete an assigned task even after school since they are more open and engaged in communication with others as a result of technological advancements. Furthermore, Kemala (2016) pointed out that learners become more motivated when they feel connected with learning mates. This is due to the fact that groupwork allows them to exchange ideas, learn from, and encourage one another.

Situational aspect covers learning resources and materials. Reinders and Balcikanli (2011) find that few textbooks contributed significantly to development of LA and many provided learners with little opportunities to practice. Tomlinson (2012, p. 143) confirms with the idea that "most commercially produced materials focus on informing their users about language features and on guiding them to 
practice these features". This implies that these textbooks offer few chances to learn a language autonomously. Kemala (2016), on the other hand, believes that materials have an influence on learners' enthusiasm and motivation. The author agrees with Harmer (2007) that learners are more likely to succeed if the contents they are learning are interesting and stimulating.

\section{RESEARCH METHODOLOGY}

\subsection{Research Design}

Mixed methods research was used in this study, allowing the author to collect and analyze data using both qualitative and quantitative methods. Therefore, it is possible to discover and explain existing relationships among variables (Creswell, 2012; Fraenkel \& Wallen, 1994). In addition, the Embedded Design was employed as the main research design. At first, only qualitative data was obtained. Then, based on such data, the author deigned questionnaire items to collect quantitative data.

\subsection{Research Setting}

The study was carried out at the Faculty of English Language of Ho Chi Minh City University of Technology, 475A Dien Bien Phu Street, Ward 25, Binh Thanh District, Ho Chi Minh City, Vietnam. At the moment, the Faculty has about 1,000 students at tertiary level minoring Business English, English for Translation and Interpretation, and English Teaching Methodology.

\subsection{Sample and Sampling Procedures}

The participants in this study were English majors in their third year of tertiary education. Table 4.1 shows the demographic data of the participants.

Table 4.1. The demographic information of participants

\begin{tabular}{|l|l|l|}
\hline Items & \multicolumn{2}{|c|}{ Result (Number) } \\
\hline Gender & Female (191) & Male (42) \\
\hline Age & $20-22(208)$ & $>22(25)$ \\
\hline Duration of learning English & 6-10 years (24) & $>10$ years (209) \\
\hline Time for learning English per day & $1-3$ hours (167) & $>3$ hours (66) \\
\hline
\end{tabular}

There were two types of samples to be used during the sampling procedures. For qualitative data, the author chose groups of participants for a focus group interview in order to develop a variety of perspectives (Creswell, 2012, p. 206); in this case, third-year students at HUTECH were chosen. Then, a two-stage random sampling was implemented to gain quantitative information using questionnaires. At first, groups of members were selected randomly, and this is called cluster random sampling. Later, for each group, members were selected with equal and independent chances. This way is known as single (individual) random sampling (Fraenkel and Wallen, 1994 and Creswell, 2012).

\subsection{Research Instrument}

The author applied focus group interviews and a close-ended questionnaire to collect data for this study.

Initially, the students participated in focus group interviews to help the author define the problems and identify variables related to the research questions. Creswell (2012) indicates that focus groups are beneficial since students who are hesitant to provide information in one-on-one interviews may feel more confident in expressing their opinions because of their close relationships with their peers. Especially, this instrument work effectively in groups of four to six students.

After that, 233 students randomly completed a closed-ended questionnaire with ready-made responses (Dörnyei \& Taguichi, 2010). In this study, some of these question items were adapted from Begum and Chowdhury (2015) and Alonazi (2017) and others were self-constructed questions based on literature provided by the authors previously mentioned. The questionnaire consisted of three main parts including 37 items. The first part consisted of 04 items that asked participants about their demographic information. The second part, which included 17 items, was designed to gather data on factors that facilitate LA, while the last part, which included 16 items, was designed to collect data on factors that inhibit LA. Likert scales were applied. The scale used for 33 items ranges from 1 strongly disagree to 5 strongly agree. 


\subsection{Data Collection and Analysis Procedures}

The current research's author requested permission from the Faculty of English Language to conduct her survey during break time (20 minutes) without any prior preparation. At first, focus group interviews were conducted in English-majored classes in order to identify some potential factors of LA. In order to collect qualified data, three groups of six students from three English-majored classes were conveniently selected to join the focus groups. Some general questions were raised and responses from all members of the group were elicited and recorded. Then, the survey was carried out with 285 questionnaires neatly delivered to 8 classes. 256 copies were returned, in which 233 were valid and used, accounting for $82 \%$ of the copies initially distributed. SPSS descriptive analysis, version 19 was applied to process quantitative data from the questionnaires. Descriptive statistics such as Means and Standard Deviations were also used to analyze the participants' responses.

\subsection{Validity and Reliability}

This study's questionnaire was initially written in English. After that, it was double-checked by a professional to ensure its accuracy and validity. Furthermore, its Vietnamese version was reviewed by a teacher of English-Vietnamese translation. Besides, 48 question items were piloted at the research site with 20 volunteer students from a class who were not among 233 participants mentioned. Through the piloting process, some questions were found to cause confusions among participants. Besides, it was admitted that the existing rating scale was unclear to answer. Therefore, the questionnaire was modified and adjusted. The second was then attempted by 20 kids from a different class. Fortunately, everyone understood what was going on this time. More worthily, SPSS was applied to measure the reliability of the questionnaire through the calculation of Cronbach's alpha index using. Table 3.4 displays the computed results for two main parts of the questionnaire which are facilitating factors and hindering factors towards LA.

Table 4.2. Reliability statistics for the questionnaire

\begin{tabular}{|l|l|l|}
\hline Contents & Cronbach's Alpha & Number of items \\
\hline Factors facilitating learner autonomy in learning English & 0.742 & 17 \\
\hline Factors hindering learner autonomy in learning English & 0.851 & 16 \\
\hline
\end{tabular}

\section{FINDING AND DISCUSSION}

\subsection{Findings of the Study}

\subsubsection{Factors Promoting English-majored Students' Autonomous Learning}

\section{Finding from Focus Group Interview}

The discussing questions aim to clarify not only internal but also external factors that help improve the autonomy among English language learners.

At first, in terms of psychological aspects, participants revealed different points of views. For example, student (S) 3 mentioned that "I always want to achieve good results in learning; therefore, I think my learning process becomes autonomous over time". S4 also confirmed "our learning is selfdirected because we are frequently under the pressure of tests and exams". Furthermore, the majority of participants insisted that they were inspired by the courses, as S6 stated "Preference on a specific course allows us to invest more time and effort studying it both in class and out of class. For example, I like "American culture", so I read about it a lot at home."

Second, it was showed that learning styles and strategies contributed greatly to the improvement of LA when all participants indicated that there are now a variety of computers software and mobile applications which enable them to study whatever, whenever and wherever they want. For example, S5 emphasized "Interaction with teachers and friends via social media, messaging apps, and emails allows me to learn a lot.". It is clear to see that these types of communication encourage students to be more self-assured and express their thoughts more freely. "The 'www' environment helps fill the gaps between spaces, and I can communicate with my friends on the other side of the world" S18 agreed.

Referring to the available skills and knowledge, interviewed students admitted that their ability to use computers and other electronic devices entitled them to be more autonomous in learning. It is believed that "Electronic devices make my learning more convenient, easy and effective.... (S17); or "...they 
assist us in producing qualified learning results, for example the reports became more appealing and eye-catching (S16).

Besides, interviewed participants reckoned that people around them influence the improvement of LA. Many of them stated that teachers had an important role in the process. For example, S7 disclosed: "Teachers put great pressure on us, so we tend to work more at home and in class to earn teachers' approval and excellent grades." Or S2 admitted: "Enthusiastic teachers motivate us to study better" Those teachers were said to assign tasks, encourage students, and check for task accomplishment on a regular basis. According to S5, he was impressed and inspired by the teachers who know what their students need and want, who care about and support students with learning and preparation methods. Furthermore, family members such as parents or siblings also play crucial roles in the development of LA. For example, S9 mentioned "My parents built up a learning habit for me from an early age, and I have been maintaining it through time." In support of this view, S13 said "My case is quite similar. I am able to guide my own learning thanks to my older brother who is currently a successful businessman. With great learning experiences, he has shaped and mentored me a lot in the process of learning English from my first days at university. My brother is a terrific model for me in terms of learning"

Furthermore, it was mentioned by some participants that textbooks bring students opportunities to study more outside of the classroom by. S14 indicated that certain of their school materials made it easy for them to learn on their own at home

Besides, learning environment is thought to place a great influence on LA as S11 declared that "Libraries and self-study rooms fully equipped with modern facilities are better places to study than rental living spaces. The learning environment there encourages us to study more efficiently."

All of these points add together to help the author of this study develop variables to the research question regarding factors enforcing LA among English-majored students.

\section{Finding from Questionnaire}

The questionnaire was designed in five-point Likert scale. For this research area, the scale ranges among 1 = Strongly disagree, $2=$ Disagree, $3=$ Neutral, $4=$ Agree and $5=$ Strongly agree . Therefore, the criteria used to interpret the data are as follows: $1.00-1.80=$ Strongly disagree, 1.81 $2.60=$ Disagree, 2.61-3.40 = Neutral, 3.41-4.20 = Agree and 4.21-5.00 = Strongly agree . Data collected for the research question was shown in table 5.1. mentioned below for 17 items.

All items in this part were adapted and designed basing on the findings from focus group interviews and theory about factors promoting the development of LA summarized in section 3 . The questionnaire is about 5 themes regarding to internal and external factors which are (1) individual aspects (items 5-8), (2) learning styles and learning strategies (items 9-11), (3) teachers (item 12-15), (4) learning materials and tasks (item 16-17), and (5) situational aspects of environment (items 1821).

Table 5.1. Factors promoting learner autonomy

\begin{tabular}{|l|l|l|l|l|}
\hline No & $\begin{array}{l}\text { Statements: } \\
\text { My autonomy in learning English is facilitated because: }\end{array}$ & N & Mean & St.D \\
\hline 5 & I know that English is of great value for my future job. & 233 & 4.69 & 0.765 \\
\hline 6 & I find extra learning activities out of classroom enjoyable. & 233 & 3.56 & 0.950 \\
\hline 7 & I want to achieve better results in learning English. & 233 & 4.64 & 0.648 \\
\hline 8 & $\begin{array}{l}\text { My knowledge of Vocabulary and Grammar makes me confident in } \\
\text { learning English. }\end{array}$ & 233 & 4.26 & 0.925 \\
\hline 9 & $\begin{array}{l}\text { I myself get access to many softwares and mobile applications to learn } \\
\text { English. }\end{array}$ & 233 & 3.76 & 0.919 \\
\hline 10 & $\begin{array}{l}\text { I myself get access to the available resources (books, journals, magazines, } \\
\text { newspapers, CDs, DVDs) at the university library. }\end{array}$ & 233 & 3.17 & 1.068 \\
\hline 11 & I prefer discovering things by myself. & 233 & 3.61 & 0.977 \\
\hline 12 & My teachers suggest/ provide me with extra learning materials. & 233 & 3.82 & 0.845 \\
\hline 13 & My teachers encourage me to find the answers on my own. & 233 & 3.70 & 0.857 \\
\hline 14 & My teachers call for any questions or enquiries. & 233 & 3.93 & 0.716 \\
\hline
\end{tabular}


Factors Affecting Learner Autonomy in Learning English at Tertiary Level: A Study at Ho Chi Minh City University of Technology

\begin{tabular}{|c|l|l|l|l|}
\hline 15 & My teachers are devoted and enthusiastic. & 233 & 4.03 & 0.871 \\
\hline 16 & $\begin{array}{l}\text { My English course books provide me opportunities to explore more after } \\
\text { class. }\end{array}$ & 233 & 3.42 & 0.984 \\
\hline 17 & I have many tasks or homework to do thanks to Workbook. & 233 & 3.36 & 0.950 \\
\hline 18 & $\begin{array}{l}\text { Audio-visual devices are available to help me to learn English } \\
\text { independently. }\end{array}$ & 233 & 3.67 & 0.987 \\
\hline 19 & Some members in my family like English. & 233 & 3.56 & 1.181 \\
\hline 20 & Many of my friends learn English well. & 233 & 4.00 & 0.963 \\
\hline 21 & My university has English learning clubs for me to join. & 233 & 2.38 & 1.089 \\
\hline
\end{tabular}

Firstly, in term of internal factors, the data in table 5.1 indicated that psychological aspects facilitated LA the most. With $\mathrm{M}=4.69,4.64,4.26$ and 3.56 respectively for items $5,7,8$ and 6 , most of participants were proved to admit their contribution. Intrinsic motives, such as understanding the potential benefits of English and desire to improve one's proficiency in the language, were thought to promote LA more than other aspects (item 5 and 7). Besides, students' language skills are an important element in enabling them to feel more confident. The positive effect of students' preferences for extra learning activities out of class was also proved in the answers to item 6 with more than $56 \%$ of surveyed students who agreed $(\mathrm{M}=3.56)$. In addition, when it comes to the impact of learning styles, almost 65 percent of participants reported that their autonomy was increased as a result of their ability to use computer software and mobile applications to study English. This is seen in Item 9 with $\mathrm{M}=3.76$.

Secondly, via the survey, it was revealed that external factors played a strategic role in helping students become more self-reliant. In terms of people, teachers were said to lay much positive influence on LA. This is demonstrated in findings from many question items. More than 76 percent of students questioned said their teachers' dedication and passion motivated them to learn (item 15) with $M=4.03$. Moreover, the acts of encouraging students to find out the answers on their own or to ask questions gave them more possibilities to make decisions on issues regarding learning and to learn independently (item 13,14) with $\mathrm{M}=3.70$ and 3.93 respectively. Furthermore, the survey illustrated that thanks to the sources of extra learning materials offered and/or suggested by teachers, participants were able to properly self-guide and execute their learning (item 12 , with $\mathrm{M}=3.82$ ). The result also revealed the impact of acquaintances such as family members and friends. The outcomes of questions 19 and 20 with $\mathrm{M}=3.56$ and 4.0, respectively, demonstrate this. Other external factors affecting the development of LA were shown to be learning materials at school and the development of digital technological gadgets when more than half of the surveyed students claiming that course books have allowed them to learn more outside of the classroom (item 16, with $M=3.42$ ). Similarly, they indicated having access to digital technological items assisted students in learning more autonomously.(item 18, with $\mathrm{M}=3.67$ ).

In conclusion, the findings pointed out that the most influential elements in the development of LA were the learners themselves and the roles of the teachers. LA were also thought to be promoted by family members, friends and educational materials.

\subsubsection{Factors Hindering English-majored Students'Autonomous Learning}

\section{Finding from Focus Group Interview}

On the subject of internal elements, nearly all of the participants agreed learner's will was the most significant one. They stated that, in addition to studying, students today have a plethora of other concerns such as part time jobs, relationships of all kinds, etc. If their willpower is not strong enough, they may devote more time and effort to these than to studying. Participants said that their autonomy in learning English could be hindered by both mental and physical condition after a certain amount of time spent for such activities. For example, S8 shared "After...part time jobs, I was too tired and sleepy to continue studying ...though I know... and want to do ...." Therefore, it was defined that lack of willpower was one of the factors inhibiting learners from achieving learning autonomy. Participants also expressed their indecisiveness when it came to choosing learning approaches. "I don't know which methods are appropriate," S4 admitted. Or S17 added "...even... not know what to learn...if...teachers do not give home assignments." Surprisingly, all of the students interviewed confirmed that they lacked either a particular learning plan or their own learning objectives. 
Moreover, they admitted that they were not confident enough to direct their learning, as S11 said "My English is not good, so I am afraid that I will not understand when reading alone."

Many participants, including S9, questioned the usefulness of learning materials in terms of external factors: "Some existing learning textbooks offer a lot of literature theory and information but little self-study tasks." Consequently, students found it difficult to prepare and review lessons through task completion. Some do, however S7 and S8 thought the activities were ready-made exercises that required little effort from students to figure out the solutions. They, therefore, believed that such books prevented them from studying independently. S8 expressed concern about teaching approaches, saying, "Sometimes I feel that my teachers wanted to 'feed' me with so much knowledge that I could overtake. I wish that they could give me some time or opportunities to digest and/or to sort it out on my own." Because they are aware that teachers would, anyway, show them the answers later, they may develop the tendency to be sluggish and refuse to discover more.

\section{Finding from Questionnaire}

It was similar with the previous research area when the author used the same design of questionnaire in five-point Likert scale ranging among 1 to 5 for Strongly disagree to Strongly agree. In addition, the criteria used to interpret the data are the same: $1.00-1.80=$ Strongly disagree, $1.81-2.60=$ Disagree, 2.61-3.40 = Neutral, 3.41-4.20 = Agree and 4.21-5.00 = Strongly agree . Data collected for 16 items of the research question was displayed in table 5.2 as mentioned hereinafter.

Table 5.2. Factors hindering learner autonomy

\begin{tabular}{|c|c|c|c|c|}
\hline No. & $\begin{array}{l}\text { Statements } \\
\text { My autonomy in learning English is promoted because: }\end{array}$ & $\mathrm{N}$ & Mean & St.D \\
\hline 22 & I do not feel confident learning by myself. & 233 & 2.94 & 1.285 \\
\hline 23 & I do not understand when studying alone. & 233 & 3.00 & 1.135 \\
\hline 24 & I am shy to talk to my teachers, friends and foreigners in English. & 233 & 3.90 & 0.887 \\
\hline 25 & I do not know what to learn after class. & 233 & 3.79 & 0.984 \\
\hline 26 & I am bad at English. & 233 & 2.49 & 1.197 \\
\hline 27 & I do not know any effective learning methods. & 233 & 2.99 & 1.165 \\
\hline 28 & I do not know how to set my own study goals for each semester and year. & 233 & 2.95 & 1.138 \\
\hline 29 & I do not know whether my learning styles are effective or not. & 233 & 3.74 & 1.068 \\
\hline 30 & $\begin{array}{l}\text { I cannot decide which learning strategies are effective for learning } \\
\text { English. }\end{array}$ & 233 & 3.19 & 1.091 \\
\hline 31 & My teachers explain everything in class. & 233 & 3.58 & 1.076 \\
\hline 32 & My teachers give the answers for all questions and exercises in books. & 233 & 3.70 & 1.028 \\
\hline 33 & I do not understand some tasks for reading / listening in my course book. & 233 & 3.60 & 1.021 \\
\hline 34 & Many topics in the course book are not authentic / out-of-date. & 233 & 3.46 & 1.070 \\
\hline 35 & $\begin{array}{l}\text { My course books do not contain many tasks that require me to think } \\
\text { critically or to discover more. }\end{array}$ & 233 & 3.77 & 0.990 \\
\hline 36 & My university library does not have enough English language books. & 233 & 3.12 & 1.084 \\
\hline 37 & There aren't many native English speakers in the area for me to talk to. & 233 & 3.54 & 1.203 \\
\hline
\end{tabular}

Similarly, all of the items in this part were adapted and designed based on the findings from focus group interviews and theory regarding factors impeding the development of LA that was outlined in section 3. The internal and external factors that have been questioned are as follows: (1) psychological aspects (items 22-24), (2) available learning skills and awareness (items 25-27), (3) learning styles and learning strategies (items 28-30), (4) teachers (items 31-32), (5) learning materials and tasks (items 33-35), and (6) environment (items 36-37).

Overall, the findings showed that learners' lack of awareness, low level of self-efficacy, poor learning styles, teachers and learning materials hindered the development of LA among English majored students. The frequency of responses to these questions is shown in Table 5.3.

Table 5.3. Frequency of items

\begin{tabular}{|l|l|l|l|l|l|}
\hline \multirow{2}{*}{ Items } & \multicolumn{5}{|l|}{ Frequency (percent) } \\
\cline { 2 - 6 } & Strongly disagree & Disagree & Neutral & Agree & Strongly agree \\
\hline Item 24 & $5(2.1)$ & $4(1.7)$ & $62(26.6)$ & $100(42.90$ & $62(26.6)$ \\
\hline Item 25 & $2(0.9)$ & $33(14.2)$ & $31(13.3)$ & $113(48.5)$ & $54(23.2)$ \\
\hline
\end{tabular}


Factors Affecting Learner Autonomy in Learning English at Tertiary Level: A Study at Ho Chi Minh City University of Technology

\begin{tabular}{|l|l|l|l|l|l|}
\hline Item 29 & $13(5.6)$ & $26(11.2)$ & $14(6.0)$ & $135(57.9)$ & $45(19.3)$ \\
\hline Item 31 & $3(1.3)$ & $55(23.6)$ & $21(9.0)$ & $112(48.1)$ & $42(18.0)$ \\
\hline Item 32 & $2(0.9)$ & $42(18.0)$ & $31(13.3)$ & $108(46.4)$ & $50(21.5)$ \\
\hline Item 33 & $12(5.2)$ & $32(13.7)$ & $19(8.2)$ & $145(62.2)$ & $25(10.7)$ \\
\hline Item 34 & $10(4.3)$ & $36(15.5)$ & $62(26.6)$ & $87(37.3)$ & $38(16.3)$ \\
\hline Item 35 & $0(0)$ & $38(16.3)$ & $33(14.2)$ & $107(45.9)$ & $55(23.6)$ \\
\hline
\end{tabular}

Learning styles, first and foremost, were seen to be the internal element that hindered LA the most. According to the data gathered, more than 77 percent of participants were unable to become autonomous due to difficulties in recognizing appropriate learning styles. In addition, information obtained at item 25 with $\mathrm{M}=3.79$ disclosed $71 \%$ of participants also found impossible to learn autonomously because they were unaware of what to learn or to do at home. Furthermore, the participants revealed that their autonomous learning was negatively affected by their embarrassment while communicating with teachers, friends and foreigners in English. This is proved by the fact that over 68 percent of participants agreed with the statement in item 24 .

Learning materials were cited by 73 percent of students as the most significant external factor impeding LA. The students revealed that failure to understand particular reading and listening texts made it harder for them to study outside of the classroom. This is shown in item 33 with $M=3.70$. In addition, as stated in item 34 with $\mathrm{M}=3.46$, more than 53 percent of the questioned students believe that learning resources containing old and out-of-date knowledge prevent them from being autonomous. Another issue raised by more than three fifths of surveyed students in relation to coursebooks was the activities in them. The result of item 35 with $\mathrm{M}=3.77$ implied that students were not motivated to work autonomously because coursebooks included few critical tasks which required them to dig deeper or to explore more after class. Another factor said to stand in the way of LA was the teachers and their teaching approaches. The finding of items 31 and 32 with $\mathrm{M}=3.58$ and 3.70 respectively showed that the influence of teachers on LA was not always good. Nearly $70 \%$ of participants pointed out that teachers' acts of giving full explanations and answers to almost every question had no positive impact on LA.

\subsection{Discussion}

\subsubsection{Factors Promoting English-majored Students' Autonomous Learning}

It is obvious from the findings that both internal and external factors play crucial roles in the development of LA at HUTECH English-majored students.

With respect to internal factors, firstly, the results informed that LA was encouraged because students not only understood the importance of English in their future careers, but also aspired to attain good academic outcomes. This is intrinsic motivation. Therefore, it is equivalent to what was mentioned by many researchers. For example, Dickinson (1992) assumed that "motivation may lead to autonomy or be a precondition for it". Likewise, Yuen Pan (1997) and Benson (2001) believed that learners' motivation and desire made them to be autonomous. Furthermore, Spratt, Humphreys and Chan (2002) illustrated that Hong Kong students with lower level of motivation seemed to be less autonomous in learning. In support of this, Chen (2015) expressed a similar viewpoint, stating that highly motivated learners are more likely to select and apply learning strategies, an aspect that favors LA

Secondly, learners' preferences for learning have been shown to help facilitate LA. The finding is somehow in line with Qin's viewpoints (2016). Qui's research revealed that once leaners become engaged in a subject, they develop favorable attitudes about learning. As a result, more attention would be paid to the subject and a learning goal would be established. This is a precondition for LA to be developed.

Thirdly, the positive influence of language knowledge was also emphasized. This finding is consistent with conclusions from Balçikanli (2010), and Tran and Duong (2018). They concluded that the more knowledge, awareness as well as learning skills students have, the more autonomous they become. Students, for example, will be more confident in their ability to learn both in and out of class if they are familiar with English grammar and vocabulary. It also corresponds to the findings of Zeng \& Liu (2014), who discovered that learning awareness leads to LA in studying oral English for Chinese students. 
Last but not least, students' learning styles contribute to the development of their LA. The opportunities to leverage technology development in learning English on their own initiatives enable HUTECH students to plan, think, monitor and evaluate own learning. In addition, they can also set their own learning targets and apply appropriate strategies to achieve them. These imply metacognitive strategies which Leaver et al (2005) and Çakici (2015) identified as a contributing factor to LA. Besides, students' preferences for self- discovery points to constructivism learning strategies, in which students derive new knowledge from their own prior knowledge. The findings appear to be consistent with those of Begum and Chowdhury (2015), and Çakici (2015).

In term of external factors, the teachers have been the most influential. The acts of suggesting or providing students with extra learning materials, encouraging them to search for their own conclusion, calling for any questions or enquiries, etc. were deemed to advocate for LA. This finding is in line with those by Leaver et al (2005) and Kemala (2016). They assumed that giving students more opportunities to make decisions or choose learning methodologies would be beneficial to them. This is also consistent with Alonazi (2017) whose findings revealed that in autonomous language classes, teachers serve as facilitators, counselors, resources and managers. Learning materials and tasks are the second determining factors. Students said their LA was improved when their learning texts gave them many opportunities to explore more outside of the classroom, according to the findings. This seemed to support Harmer (2007) and Kemala (2016)'s idea indicating that stimulating, interesting and challenging tasks would motivate students to work not only independently but also interdependently.

Another external factor influencing LA is the people around the students. The surveyed students admitted being motivated by family members and friends who are good at English. This finding was backed up by Dang (2010) and Kemala (2016), who concluded that social context contributed to the formation of an interactive learning environment.

In summary, various internal and external factors were shown to contribute to learner autonomy. Individual factors as motivation, linguistic knowledge, learning preferences, and learning styles all have a role in the promotion of LA. On the other hand, there are external factors as teachers, learning materials and tasks, as well as family members and friends.

\subsubsection{Factors Hindering English-majored Students' Autonomous Learning}

The first internal factor cited as contributing to poor performance of LA is the unawareness of what to learn outside of the English classroom. This result is equivalent to what Balçikanli (2010) reported that a lack of learning skills and knowledge resulted in poor performance of autonomous learning. It is also backed up by demographic data collected, which revealed that most participants spent less than 3 hours per day studying outside of class. This finding is somehow similar to the above-mentioned results for language knowledge contributing to LA, which showed that once students have sufficient knowledge, awareness as well as learning skills, they become more autonomous, as supported by researchers such as Zeng and Liu (2014), Tran and Duong (2018).

The second factor that has been identified as a barrier to LA is student's self-efficacy. Students will be unable to interact, talk, or express their own viewpoints due to their lack of confidence in communicating in English with others. Wenden (1998) pointed out that this status has proved to affect learning performance because students who doubt their abilities to learn may refuse to spend enough time and efforts in studying. Also, studies from Leaver et al (2005), Chen (2015), and Ou (2017) confirm the positive impact on LA. Consequently, it is assumed that a lack of self-efficacy could lead to poor learner autonomy performance. The result for this factor is consistent with the prior finding herein on self-awareness and language knowledge since a person cannot be confident if he knows little about the thing.

Teachers, on the other hand, are thought to be an external factor that obstructs LA. According to the questionnaire result, teachers were said to explain everything in class and to tend to give answer to almost every question and activity in the coursebook. Students in a focus group said that teachers often provided them explanations for structures and vocabulary. Such actions make students become lazier and have a tendency to wait for teachers' explanation rather than discovering things by themselves. This refers to a trait of positivism learning theory which is believed to hinder the enhancement of LA (Begum \& Chowdhury, 2015). The last factor which is believed to impede the 
promotion of LA is learning materials. For students, this is due to the fact that most learning materials are irrelevant, containing old and obsolete information and there are little opportunities for them to study and explore more after school. The results are similar to those of other researchers such as Kemala (2006) who emphasized that infeasible and uninteresting tasks cannot arouse students' motivation to learn. This is also in line with findings by Reinders and Balcikanli (2011). The authors found that textbooks either contributed little to the improvement of LA or offered learners limited chances to practice. Similarly, Tomlinson (2012, p. 143) confirmed that the majority of commercially produced resources used as popular learning materials at universities "focus on informing their users about language features and on guiding them to practice these features" not on giving opportunities for students to explore more about additional things while self-discovery is regarded as one of the most essential characteristics of autonomous learners. In addition, Tran and Duong (2018) claims that once students cast their doubt on the usefulness of learning materials, they will never develop autonomous learning.

\section{CONClusion}

\subsection{Summary of the results}

To sum up, this study identified a number of factors that support, as well as those that inhibit, autonomous English acquisition among HUTECH English-majored students. Students' intrinsic motivation, English language skills, learning preferences, and learning styles and tactics were all found to be advantageous internal factors. Meanwhile, teachers, teaching and learning materials, as well as the people surrounding, such as family and friends, have been suggested as factors to foster LA.

Individual aspects such as students' lack of learning skills and language awareness, improper learning methods and low level of self-efficacy were also noted as obstructing factors toward autonomous learning. In relation with outside influencers, teachers and teaching and learning materials were shown to affect LA in negative ways.

\subsection{Pedagogical Implications}

\subsubsection{Implications for Teachers}

From the discovery of factors influencing LA among English-majored students, teachers are recommended to modify their teaching approaches so that students are assisted with more opportunities to make decisions, to solve problems and to discover things by themselves. Also, teachers play a vital role in motivating students and boosting their confidence in learning, which is crucial for better autonomous learning. Furthermore, in terms of coursebooks, teachers are encouraged to be creative in their teaching adaptations or adjustments in order to stimulate students to learn English.

\subsubsection{Implications for Students}

It is encouraged that students should have their own learning objectives and strategies. Thus, they are advised to set proper learning goals and develop appropriate ESL learning strategies. Furthermore, it is suggested that the use of current technology should be enhanced in order to create an autonomous learning environment.

\subsection{Recommendations for Further Research}

The presence of limitations in this study is inevitable. Firstly, there was a lack of class observations to determine and consider the correlation with findings from questionnaires. Secondly, the author of this research failed to include the perspectives from other teachers of English. Therefore, numerous changes are expected to be implemented in the future for a better research. The first change would be to the research instrument. It is necessary to include class observations in order to bring in more data for discussion. Furthermore, future research should broaden the scale of the sample to include students from other different majors. Besides, teachers should be included in the research for a diversity of perspectives. Last but not least, the study also suggested that, in the framework of this research, another study should be conducted to look into what teachers do to support English-majored students in their learning. 


\section{REFERENCES}

[1] Alonazi, S. M. (2017). The role of teachers promoting learner autonomy in secondary schools in Saudi Arabia. English Language Teaching, 10 (7), 183-202.

[2] Balçikanli , C. (2010). Learner autonomy in language learning: Student teachers' beliefs. Australian Journal of Teacher Education, 35(1)90-103.

[3] Begum, A., N. \& Chowdhury, R., F. (2016). The factors that affect learner autonomy in learning English as a foreign language (EFL) at tertiary level in Bangladesh. Elk Asia Pacific Journal of Social Sciences. 2 (4).

[4] Benson, P. (2001). Teaching and researching autonomy in language learning. London: Longman.

[5] Breen, M. P. \& Mann, S. J. (1997). Shooting arrows at the sun: Perspectives on pedagogy for autonomy. In P. Benson \& V. Voller, Autonomy and independence in language learning. New York: Longman

[6] Çakıcı, D. (2015). Autonomy in language teaching and learning process. İnönü Üniversitesi Eğitim Fakültesi Dergisi, 16(1), 31-42. DOI: 10.17679/iuefd.16168538

[7] Chen, H. (2015). The correlations between learner autonomy and the affective factors in college English learning in China. International Review of Social Sciences and Humanities, 8(2), 70-84.

[8] Coopersmith, S. (1967). The Antecedents of Self-Esteem. San Francisco: Freeman.

[9] Crabbe, D. (1999). Learner autonomy and the language teacher. In C. Ward \& W. Renandya (Eds.), Language teaching: New insights for the language teachers. SEAMEO Regional Language Centre. Anthology Series 40, 242-258.

[10] Creswell, J. W. (2012). Educational Research: Planning, conducting and evaluating quantitative and qualitative research. USA: Pearson Education.

[11] Dang, T. T. (2010). Learner autonomy in EFL studies in Vietnam: a discussion from sociocultural perspective. English Language Teaching Journal 3(2), 3-9.

[12] Dickinson, L. (1992). Learner autonomy: Learner training language learning. Dublin: Authentic.

[13] Dinh, T. H. T. (2017). An overview of research on foreign language learning autonomy in Vietnam. VNU Journal of Foreign Studies, 33 (5), 123-130.

[14] Dörnyei, Z. \& Taguichi, T. (2010). Questionnaires in second language research: Construction, administration, and processing. New York: Routledge.

[15] Fraenkel, J. R. \& \& Wallen, N. E. (1994). How to design and evaluate research in education. USA: McGraw-Hill.

[16] Harmer, J. (2007). The Practice of English Language Teaching (4 ${ }^{\text {th }}$ ed.) Edinburgh: Pearson Longman.

[17] Hasim, Z. B. \& Zakaria, A. R. (2015). ESL teachers" knowledge on learner autonomy. In F. L. Gaol, F. Hutagalung, A. R. Zakaria \& Z. B. Hasim (eds). Knowledge, Service, Tourism \& Hospitality: Proceedings of The Annual International Conference on Management and Technology In Knowledge, Service, Tourism \& Hospitality. Bandung: CRC Press.

[18] Holec, H. (1981). Autonomy and Foreign Language Learning. Oxford: Pergamon Press.

[19] Kemala, Z. (2016). An Analysis of factors influencing the autonomous learners in learning English. ELTIN Journal, 4(1), 11-20.

[20] Leaver, B. L., Ehrman, M. \& Shekhtman, B. (2005). Achieving success in second language acquisition. Cambridge: Cambridge University Press.

[21] Little, D. (1996). Freedom to learn and compulsion to interact: Promoting learner autonomy through the use of information systems and information technologies. In R. Pemberton, E. Li, W. Or, \& H. Pierson (Eds.), Taking Control: Autonomy in Language Learning (pp. 203-218). Hong Kong University Press.

[22] Little, D. (2000). Why focus on learning rather than teaching? In D. Little, L. Dam, \& J. N Timmer (Eds.), Focus on Learning Rather than Teaching: Why and How? Papers from the International Association of Teachers of English as a Foreign Language.

[23] Littlewood, W. (1996). “Autonomy”: An anatomy and a framework. System, 24, 427-435.

[24] Morbedadze, D. (2015). Learner autonomy. International Journal of Educational Investigations, 2(10), 19.

[25] Nguyen, L. V. (2010). Computer mediated collaborative learning within a communicative language teaching approach: A sociocultural perspective. The Asian EFL Journal Quarterly, 12(1), 202-233.

[26] Nguyen, T. V. (2011). Language learners' and teachers' perceptions relating to learner autonomy - Are they ready for autonomous language learning? Vietnam National University Journal of Science, Foreign Languages, 27, 41-52. 
[27] Nguyen, V. L., Chung, T. T. H., Truong, N. Q. N.\& Pham, T. M. D. (2014). Promoting learner autonomy among students of English: Beliefs of english language lecturers in some universities. Can Tho University Journal of Science, 3, 75-83.

[28] Ou, C. (2017). A Review on Language Learner Autonomy Research in China (2006-2016): Based on 12 Key Domestic Journals. English Language Teaching, 10(11), 76-86.

[29] Pham, T. N. (2010). The higher education reform agenda: A vision for 2020. In G. Harman, M. Hayden \& N. T. Pham (Eds.), Reforming higher education in Vietnam: Challenges and priorities (1st ed., pp. 51-64). London: Springer.

[30] Qin, J. (2016). On Cultivation of Autonomous Learning Competence in College English Listening Teaching. Sino-US Teaching, 13(11), 842-846.

[31] Reinders, H. \&Balcikanli, C. 2011. Do classroom textbooks encourage learner autonomy? Novitas Royal. 5(2), 265-272.

[32] Richards, J.C. \& Rodgers, T. S. (2015). Approaches and Methods in Language Teaching. Cambridge: Cambridge University Press.

[33] Spratt, M., Humphreys, G. \& Chan, V. (2002). Autonomy and motivation: which comes first?. Language Teaching Research, 6(3), 245-266.

[34] Scharle, A. \& Szabó, A. (2000). Learner Autonomy: A Guide to Developing Learner Responsibility. Cambridge: Cambridge University Press.

[35] Tomlinson, B. (2012). Materials development for language learning and teaching. Language Teaching, 45(2), 143-179. doi: 10.1017/S0261444811000528

[36] Tran, Q. T. \& Duong, M. T. (2018). EFL Leaners' perceptions of factors influencing learner autonomy development. Kasetsart Journal of Social Sciences. 1-6.

[37] Wenden, A. (1998). Learner Strategies for Learner Autonomy. Great Britain: Prentice Hall.

[38] Yuen Pan, D. (1997). Lifelong learning: The whole damn cycle-a Singapore perspective. In M. J. Hatton (Ed) Lifelong Learning. Toronto: The School of MediDiffea Studies.

[39] Zaqiri, L. (2015). The influence of foreign language anxiety on learner autonomy. In B. Xhafferri, M. Waldispühl, B. Eriksson-Hotz and G. Xhafferri (Eds), Promoting learner autonomy in high education, International Conference at South East European University in Tetovo (pp. 133-146).

[40] Zeng, C. \& Liu, C. (2014). Modeling influential factors on learner autonomy in oral English in the Chinese EFL context. English linguistics research. 3 (2), 103-114. DOI: 10.5430/elr.v3n2p103

\section{AUTHORS’ BIOGRAPHIES}

Mrs. Tran Thi Bich Tram, is currently a full-time lecturer of English at Van Lang

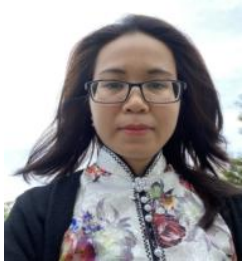
University. She got a master degree in Business Administration at University of Bolton in 2012 and earned her Master's Degree in English Language at Ho Chi Minh City University of Technology in July 2019. She is into academic areas such as TESOL methodology, language skills, and Business English.

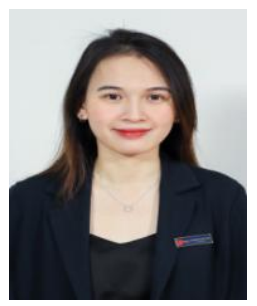

Ms. Vuong Tuyet Kha, is currently a full-time lecturer of English at Van Lang University. She has a Bachelor degree in International Business Administration at Foreign Trade University HCM and a Master degree in TESOL at University of Huddersfield, UK. She has particular interest in teaching language skills, academic writing and English for Specific Purposes.

Citation: Tran Thi Bich Tram, M.A, Vuong Tuyet Kha, M.A. "Factors Affecting Learner Autonomy In Learning English At Tertiary Level: A Study At Ho Chi Minh City University Of Technology” International Journal on Studies in English Language and Literature (IJSELL), vol 9, no. 6, 2021, pp. 12-25. doi: https://doi.org/10.20431/2347-3134.0906002.

Copyright: (c) 2021 Authors. This is an open-access article distributed under the terms of the Creative Commons Attribution License, which permits unrestricted use, distribution, and reproduction in any medium, provided the original author and source are credited. 